\title{
SPECIES DIVERSITY OF BATS IN THE SKOLE BESKIDS NATIONAL NATURE PARK
}

\author{
Yuriy Chaika, Oleksandr Kusnezh \\ Ivan Franko National University of Lviv, Faculty of Biology (Lviv, Ukraine) \\ Correspondence to: O. Kusnezh; Hrushevsky St. 4, Lviv 79005 Ukraine; \\ e-mail: oleksandr.kusnezh@gmail.com
}

\begin{abstract}
Species diversity of bats in the Skole Beskids National Nature Park. - Yu. Chaika, O. Kusnezh. - In total, 21 species of bats were found in the Skole Beskids National Nature Park. Among them, six species were recorded in the territory of the Park form the first time: Rhinolophus ferrumequinum, Myotis brandtii, M. alcathoe, M. dasycneme, Plecotus austriacus, and Nyctalus leisleri. Additionally, R. ferrumequinum was recorded in Lviv region for the first time as well. During the summer, we observed 16 species of bats in the Park. The abundance of bats during this season was not very high, and the places with their most explicit activity were the Zhuravlyne and Polianetske lakes. It was established that 10 species take part in the fall swarming. The most abundant species during swarming was Myotis myotis. The period of swarming lasted from the beginning of September to the end of October. During the period of hibernation, 11 species of bats were observed. The bats were found in 5 of 15 examined caves on Kliuch mountain. The period of hibernation during the 2015/2016 season lasted from the third decade of November to the third decade of March.
\end{abstract}

Key words: bats, species diversity, hibernation, swarming, Skole Beskids.

Видовий склад рукокрилих Національного природного парку Сколівські Бескиди. - Ю. Чайка, О. Кусьнеж. - Для НПП «Сколівські Бескиди» виявлено 21 вид рукокрилих. Протягом досліджень було виявлено шість нових для території Парку види: Rhinolophus ferrumequinum, Myotis brandtii, M. alcathoe, M. dasycneme, Plecotus austriacus, Nyctalus leisleri. Rhinolophus ferrumequinum виявлений вперше для території Львівської області. Під час літнього періоду у НПП трапляється 16 видів рукокрилих. Чисельність кажані протягом цього періоду не висока, місця найбільшої активності оз. Журавлине, оз. Полянецьке. Встановлено, що в осінньому роїнні беруть участь представники 10 видів рукокрилих. Найчисельніший вид на роїнні - M. myotis. Період роїння тривав 3 початку вересня до кінця жовтня. У період гібернації відмічено представників 11 видів рукокрилих. Кажани виявлені нами у 5 із 15 обстежених печер г. Ключ. Період зимівлі у сезон 2015/2016 рр. тривав із III декади листопада до III декади березня.

Ключові слова: рукокрилі, видове різноманіття, гібернація, роїння, Сколівські Бескиди.

\section{Introduction}

The order of Chiroptera is among the least studied groups of mammals in Ukraine. Bat species are included into a number of red lists and they are in need of protection based on their census, identification of shelters and respective monitoring of the state of populations. The Ukrainian Carpathians, namely the mountainous part of the Skole Beskids National Nature Park is not an exception. Previous studies in the area were held in 2000 and 2005 by A.-T. Bashta. Due to the large territory of the Park, however, it is crucial to learn more about its climatic and geological features to characterize more precisely the distribution of bats in the Ukrainian Carpathians. Tectonic caves in the territory of the Skole Beskids provide shelters for hibernation and autumn migration of bats in Prykarpattia and in the Ukrainian Carpathians, and therefore they need to be examined.

The goal of the present research was to ascertain the species composition of Chiroptera in the Skole Beskids National Nature Park, identify the places of hibernation and swarming of bats, as well as to compare the number of bats in different periods of the year. 


\section{Material and methods}

The research was conducted during 2013-2016 mainly in the territory of Skole and Maidan forestries of the Skole Beskids NNP, reserve tract "Zuravlyne," located at an altitude of $600 \mathrm{~m}$ a.s.l., along the waterfalls of the Kamianka river, along the Parkski Range and the Middle Range, along the Kluchniy river, and near the Polianetske lake. The study is based on our own observations and on literature data.

The main methods of fieldwork during the summer and fall periods were the netting method and the transect method using an ultrasonic detector (D200 Pettersson). Aiming to study the winter diversity of Chiroptera, the main places of bats' hibernation in the territory of the Skole Beskids NNP were examined. The caves were visited through the fall-to-spring period with different periodicity. The monitoring was carried out with minimal disturbance for the animals, only active individuals and not clearly identifiable ones were netted.

In all of the caught specimens, the species and sex were determined, and the length of the forearm was measured. When working with animals, we followed the instructions of the Guidelines of the American Society of Mammalogists regarding the use of wild mammals in research (Sikes, Gannon, 2011). After identification and making measurements, all animals were released.

During the research, 15 caves located on the slopes of Kliuch Mt. were explored and identified as potentially suitable places for bats to live in (Table 1). The largest accumulation of bats was revealed in the Pilgrim and Kliuch-1 caves (the latter is a temporary name given to ease the identification of survey sites).

Pilgrim is the largest of the caves examined. The total length of cave passages reaches $600 \mathrm{~m}$. The cave is divided into 3 large halls. The temperature in the first room is $+8^{\circ} \mathrm{C}$, in the second room $+7{ }^{\circ} \mathrm{C}$, and in the third room $+7^{\circ} \mathrm{C}$.

Kliuch-1. The total length of cave passages does not exceed $300 \mathrm{~m}$. The cave has two closely located entrances: a vertical and a horizontal. The vertical entrance is round and $3 \mathrm{~m}$ wide. The size of the horizontal one is $2.5 \times 2 \mathrm{~m}$. The caves represent a long crack that extends from the bottom to the top of the mountain. In the first part of the cave the temperature is $+2-3^{\circ} \mathrm{C}$, while in its second part is $+6^{\circ} \mathrm{C}$.

Other cavities. In addition to the main hibernation places described above, bats were also found in three shallow caves of up to $40 \mathrm{~m}$ in length. Due to small entrances, the temperature inside them is stable $\left(+7.5-8{ }^{\circ} \mathrm{C}\right)$. No bats were found in ten other examined cavities.

\section{Species diversity of bats during summer}

The overall number of bats during summer is comparatively small in the area. The bats are commonly found close to mountain lakes, reservoirs, river valleys, and in anthropogenic landscapes. During the summer in 2014 and 2015, bats were netted near the Zhuravlyne (Mertve) lake and by the reservoirs near Dovhe village and the Polianetske lake that is located close to the border of the Park in vicinities of Polianytsia village, Dolynskyi district.

The trapping location near the water reservoirs was chosen due to the higher number of specimens of Chiroptera here compared to other terrains.

The largest number of individuals of diverse species was netted near the Zhuravlyne lake. A total of 9 species were found there: P. auritus $(07.19 .2014-1 \delta, 7.07 .2015-2 \lambda)$, Eptesicus serot-

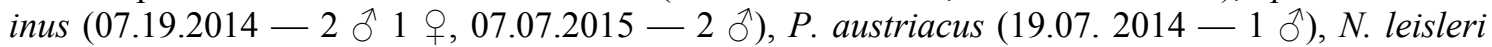
(07.19.2014 - 1 §), M. mystacinus $(07.19 .2014-1$ §), M. brandtii $(07.07 .2015-1$ §), Myotis

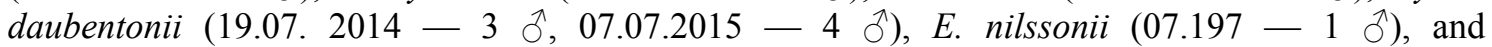
M. dasycneme (07.19.2014 - 1 ठ, 07.07.2015 - 1 §). The largest number of individuals netted was of M. daubentonii ( 7 specimens). The confinement of bats to this reservoir (Zhuravlyne lake) can be explained by the high abundance of insects (which is due to thick vegetation cover and marshy landscape) and the presence of an old forest located nearby. 
Table 1. The results of bat censuses during winter 2015-2016 (total number in all caves)

Таблиця 1. Результати зимових обліків рукокрилих у 2015-2016 рр. (кількість особин в усіх печерах)

\begin{tabular}{lcccc|c|c|c}
\hline Species & 15.11 .2015 & 11.12 .2015 & 20.12 .2015 & 15.01 .2016 & 13.02 .2016 & 19.03 .2016 \\
\hline M. myotis & 18 & 29 & 27 & 28 & 30 & 34 \\
R. hipposideros & 2 & 0 & 1 & 1 & 1 & 2 \\
R. ferrumequinum & 1 & 0 & 0 & 0 & 0 & 0 \\
Pl. auritus & 0 & 1 & 0 & 1 & 1 & 0 & 0 \\
M. bechsteinii & 0 & 2 & 1 & 0 & 0 & 0 \\
M. brandtii & 0 & 0 & 1 & 0 & 0 & 1 \\
M. dasycneme & 0 & 0 & 0 & 2 & 0 & 1 \\
B. brandtii & 0 & 0 & 0 & 0 & 1 & 0 \\
E. nilssonii & 0 & 0 & 0 & & & 0 \\
\hline
\end{tabular}

There were 4 species of bats found near the Polianetske lake: E. nilssonii $(20.07 .2014-1$ đ),

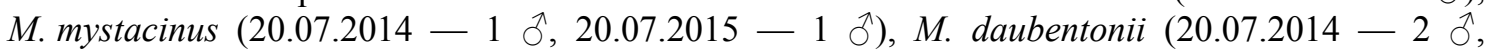

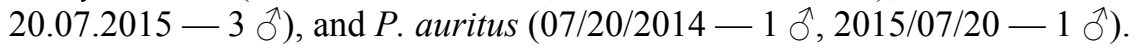

At the reservoir near Dovhe village, records and catches were carried out on 29 July 2014 and 15 July 2015. Because of uncommon location and often nearby flights, catches were ineffective. According to the data received using the ultrasonic detector, however, specimens of $M$. daubentonii could be most likely found in the area. The less number of bats and the record of only one species can be explained by several factors: 1) low density of aquatic vegetation, which leads to a relatively low number of insects; 2) the absence of forests or old hollow trees near the lake, as well as other bat shelters; 3 ) the reservoir's history is relatively short and yet it may not be fully inhabited by bats.

To study the bat fauna with an ultrasonic detector the authors also laid out transects near the Zhuravlyne (Mertve) lake, along the valleys of the Kamianka and Luzhky rivers within the Park, on the slopes of Kliuch Mt., along the Stryi river near Dovhe village, Drohobych district. The studies were conducted in 2014-2015, during June and July.

During ultrasonic records on the route near the Zhuravlyne (Mertve) lake, a few individuals of Myotis daubentonii, Nyctalus noctula, Pipistrellus nathusii and one specimen of Barbastella barbastellus were found. On the route along the Kamianka and Luzhky rivers near Kamianka village, specimens of the following species were recorded: Nyctalus noctula, Eptesicus serotinus, and Myotis daubentonii. Along the Stryi river near Dovhe village, a significant cluster of specimens of Nyctalus noctula and a few individuals of Eptesicus serotinus were discovered.

In the middle of July 2015, a census of bats by detectors was carried out on Parashka Mt. and the neighbouring mountain chain, at altitudes of 1100-1200 m. During census, the activity of bats was not revealed, which can confirm the bats adherence to the reservoirs.

In total, 16 species of bats were found during the summer in the territory of the Skole Beskids NNP, namely Plecotus auritus, P. austriacus, Barbastella barbastellus, Myotis myotis, M. daubentonii, M. dasycneme, M. mystacinus, M. brandtii, Pipistrellus nathusii, P. pipistrellus, P. pygmaeus, Eptesicus nilssonii, E. serotinus, Vespertilio murinus, Nyctalus noctula, and $N$. leisleri. Three species from this list $-P$. pipistrellus, $P$. pygmaeus, V. murinus - are known from the literature (Bashta, 2005; Ivashkiv, Bashta, 2011) but were not recorded during this study.

According to the data from literature (Bashta, 2005) and the results of current research, the most abundant species during summer are Myotis daubentonii, Eptesicus serotinus, and Nyctalus noctula. Among them, E. serotinus was the most often observed species in urban landscapes and adjacent areas. Specimens of $N$. noctula prefer river valleys and lowlands where old trees are present, but often hunting at significant altitudes. Myotis daubentonii predominates in areas near natural and artificial reservoirs and ponds (Bashta, 2000, 2005; Ivashkiv, Bashta, 2011).

The low number of females caught near the lakes in the summer can be explained by difficult climatic conditions for rising the offspring (short warm period of the year and low temperatures). 


\section{Species diversity of bats during winter hibernation}

The studies of winter bat shelters were carried out on the slopes of Kliuch Mt., where the largest number of caves in the Skole Beskids NNP is located. The problem we had to deal with was the total absence of any information about the exact location of the caves. As a result, not all caves that are known in the area were found. Considering the expected large number of caves that were not found, the number of caves with entrances too narrow for humans, the presence of hard-to-reach caves and separate halls of the caves, as well as a large number of narrow and long slits, the number of species and individuals presumably are to be higher. Bats were discovered in 5 of 15 examined caves and hollows of Kliuch Mt.

During the studies, 11 hibernating bat species were found such as Rhinolophus hipposideros, R. ferrumequinum, Myotis myotis, M. bechsteinii, M. dasycneme, M. mystacinus, M. alcathoe, M. brandtii, Plecotus auritus, Barbastella barbastellus, Eptesicus nilssonii. The largest number of hibernating bats belonging to 7 species was found in the Pilgrim cave: $R$. hipposideros, $R$. ferrumequinum, M. myotis, M. bechsteinii, M. alcathoe, M. brandtii, and $P$. auritus. The largest variety was observed in the cave No. 1, in which 8 species were found: R. hipposideros, M. myotis, M. bechsteinii, M. dasycneme, M. brandtii, P. auritus, B. barbastellus, and E. nilssonii.

Single individuals of three species (Rhinolophus hipposideros, Myotis bechteinii, and M. mystacinus) were found in three other small caves.

The most abundant hibernating species in the caves of Kliuch Mt. is Myotis myotis, which confirms the previous research by A.-T. V. Bashta, who revealed up to 11 individuals (2000). The total number of individuals identified in each cave varied from 16 to 36 individuals, while the Pilgrim cave was the place of their largest accumulation. The only one species found in all of the examined caves was Rhinolophus hipposideros.

During the winter of 2014-2015, the greater horseshoe bat (Rhinolophus ferrumequinum) was registered for the first time in the territory of the Skole Beskids NNP. Individuals of this species were found particularly in the Pilgrim cave $(850 \mathrm{~m}$ a.s.1.) in the second part of the cave, in a narrow grotto at a height of $1.5 \mathrm{~m}$. This finding is of particular interest as it is the first record of the species in the territory of the Lviv region.

The hibernation period of bats in the 2015/2016 season lasted from the third decade of November to the third decade of March. In the summer, species of Chiroptera were not detected in caves. The bats begin to use caves from the fall migration that starts from the third decade of August and the first decade of September.

The total number of bats found during the current study in the mountain caves is relatively moderate. The total number of individuals during each registration in all five caves did not exceed 40 individuals. In fact, the bats can use not only large caves for hibernation, but also various small cracks and cracks in the outputs of solid geological rocks (Strelkov, 1970; Borissenko et al., 1999; Vlaschenko, Naglov, 2005). The high number of such cracks on Kliuch Mt., as well as the relatively high number of bats in the fall swarming period may indicate the potential to host hibernation for significantly more number of bats in the area.

\section{Species diversity of bats during the fall swarming period}

The fall swarming is a phenomenon when a large number of bats is gathered up near an underground shelter. This behavior of bats is an integral part of the fall migration aiming to find a place for hibernation. During the time of swarming, pairing and sharing of social information between individuals of the population can be observed (Dietz et al., 2009).

During the fall swarming, the catches were carried out near the main place of their hibernation, i.e. the Pilgrim cave. During 2014-2015, 7 night-time catches were accomplished. In particular, during the first netting on 20 September and 13 October 2014, 7 individuals of 3 species were caught,

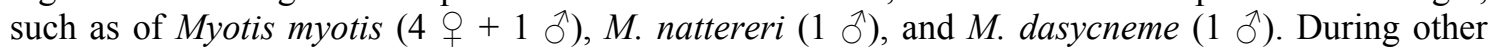
catches, 31 specimens of 7 species were netted: Rhinolophus hipposideros $(1 \stackrel{0}{1})$, Myotis myotis $(2 q$ 


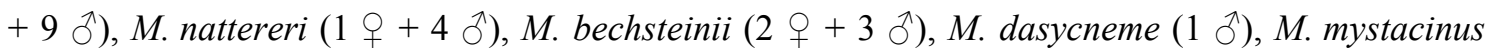

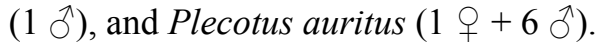

In 2015, nettings were held more systematically and a total of 184 bats were caught during 5 surveys in September to October (fig. 1) that belonged to 10 species: Rhinolophus ferrumequinum $(1 \precsim)$, R. hipposideros $(2 \precsim)$, Myotis myotis $(54 q+45 \precsim)$, M. nattereri $(4 q+22 \precsim)$, M. bechsteinii $(3 q+10 \hat{\jmath}), M$. dasycneme $(1+3 \hat{\jmath})$, M. daubentonii $(2+$ + $)$, M. mystacinus $(6 \hat{\jmath})$, Plecotus auritus $(7 q+17 \overbrace{}^{\top})$, and Barbastella barbastellus $(2 q+1 \overbrace{}^{\top})$.

In the catches during 2014 and 2015, the greater mouse-eared bat (Myotis myotis) predominated with 115 individuals. Large numbers of individuals are also observed for species M. nattereri, M. bechsteinii, and Plecotus auritus. For the rest of the species, there are several discoveries. For all species, except for M. myotis, the number of males was significantly higher than of females. The largest number of bats was netted in mid-September, which coincides with the highest catch of M. myotis. According to the studies, the number of individuals of the greater mouse-eared bat began to decline in the second half of September. Instead, the number of individuals of M. nattereri and $P$. auritus began to increase at this time (fig. 1).

In 2015, the fall swarming was observed from the beginning of September until the end of October. The peak of the swarming activity near the caves was observed 2-3 hours later after sunset. A second set-off of bats before dawn was not observed. The rest period between swarming and hibernation is considered absent for the greater mouse-eared bat. The activity of bats was gradually reducing and the swarming proceeded into hibernation. Notably, the largest number of catches coincides with the best weather conditions during the fall period.

\section{Conclusions}

As a result of the research held, it was determined that 21 of the 23 species known for the Ukrainian Carpathians region are present in the territory of the Skole Beskids NNP. Among them, the presence of 15 species in the Park was confirmed, while the other 6 species (Rhinolophus ferrumequinum Myotis brandtii, M. alcathoe, M. dasycneme, Plecotus austriacus, Nyctalus leisleri) were recorded for the first time. The species $R$. ferrumequinum was also first registered in the entire Lviv region. In the summer, 16 species of bats were found. The most numerous species were Myotis daubentonii, Nyctalus noctula, and Eptesicus serotinus. During the hibernation period, specimens of 11 bat species were discovered.

Bats were found in 5 of the 15 explored caves of Kliuch Mt. The most abundant species was the greater mouse-eared bat, M. myotis. The total number of identified individuals of this species on each site varied from 16 to 36 individuals, and the Pilgrim cave was the place of their largest accumulation. It was revealed that 10 species of bats are involved into the fall swarming. The most numerous species during swarming was M. myotis.

The period of swarming lasted from the beginning of September until the end of October. The peak of activity in 2015 was in the end of the second decade of September.

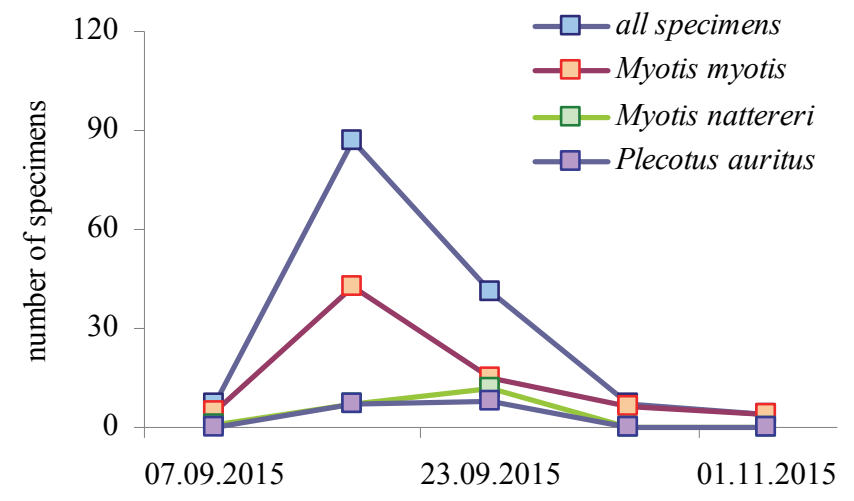

Fig. 1. The dynamics of the abundance of bats during autumn swarming near the caves on Kliuch Mt. in 2015.

Рис. 1. Динаміка чисельності рукокрилих під час осіннього роїння поблизу печер г. Ключ у 2015 p. 


\section{References • Література}

Akimov, I. A. (ed.). 2009. Red Book of Ukraine. Animal World. Global-Consulting Kyiv, 1-545. (In Ukrainian)

[Акімов, І. А. (ред.). 2009. Червона книга України. Тваринний світ. Глобалконсалтинг, Київ, 1-545.]

Bashta, A.-T. V. 2000. Observation of rare bat species (Mammalia, Chiroptera) in the Beskids (Ukrainian Carpathians). Vestnik zoologii, 34, № 3: 66. (In Ukrainian)

[Башта, А.-Т. В. 2000. Знахідки рідкісних видів рукокрилих (Mammalia, Chiroptera) в Бескидах (Українські Карпати). Вестник зоологии, 34, № 3: 66.]

Bashta, A.-T. V. 2005. Bat fauna (Chiroptera) of Skole Beskyds (Ukrainian Carpathians). In: Research on Objects of Nature Reserve Fund of the Carpathians and the Preservation of Natural Ecosystems in the Context of Sustainable Development. Yaremche, 8-13. (In Ukrainian)

[Башта, А.-Т. В. 2005. Фауна рукокрилих (Chiroptera) peгіону Сколівських Бескид (Українські Карпати). Наукові дослідження на об'єктах природно-заповідного фонду Карпат та збереження природних екосистем в контексті сталого розвитку. Яремче, 8-13.]

Ivashkiv I. M., A.-T. V. Bashta. 2011. Specific composition and features of the spatial distributing of bats in the urboecosystems of Beskids. Scientific Bulletin of Ukrainian National Forestry University, 21.16: 123-126. (In Ukrainian)

[Івашків, І. М., А.-Т. В. Башта. 2011. Видовий склад та особливості просторового розподілу рукокрилих урбоекосистем бескидів. Науковий вісник НЛТУ Украйни, 21.16: 123-126.]

Strelkov, P. P. 1970. Migratory and stationary bats (Chiroptera) of the European part of the Soviet Union. Bulletin of Moscow Society of Naturalists. Biological Series, 75, pt. 2: 38-52. (In Russian)

[Стрелков, П. П. 1970. Оседлые и перелетные виды летучих мышей (Chiroptera) в Европейской части СССР. Coобщение 1. Бюллетень Московского общества испьт. прир. Отд. биол., 75, вып. 2: 38-52.]

Borissenko, A. V., S. V. Kruskop, V. N. Chernyshev. 1999. A bat hibernation site in Moscow region. Plecotus et al., 2: $124-125$.

Dietz, C., O. Helversen, D. Nill. 2009. Bats of Britain, Europe, and Northwest Africa. A \&C Black Publisher Ltd., London, $1-400$.

Sikes, R. S., W. L. Gannon. 2011. The Animal Care and Use Committee. Guidelines of the American Society of Mammalogists for the use of wild mammals in research. Journal of Mammalogy, 92: 235-253.

Vlaschenko, A., A. Naglov. 2005. A marl open pit as a unique place of bats (Chiroptera) inhabiting. Vestnik zoologii, 39 (2): 94. 